\title{
INTERNATIONAL MANUFACTURING: AN ANALYSIS ON FACTORY LEVEL OF THE CENTRE-PERIPHERY RELATIONS
}

\author{
A.D.M. van de Ven \\ Eindhoven University of Technology, P.O. Box 513,5600 MB Eindhoven (The Netherlands)
}

\begin{abstract}
This article deals with the position of industries in the western countries in their relation to the industrial capacities of the periphery countries, especially the newly industrializing countries. The weaknessess and strengths of manufacturing systems in periphery countries are discussed, and conclusions are drawn concerning the selection and design of manufacturing systems in these countries and their international competitiveness.
\end{abstract}

Furthermore, an international productionallocation model is presented, which determines the optimum location of manufacturing systems of internationally tradeable products and analyzes the sensitivity to competition from the periphery countries of the different industries in the centre countries.

Finally, the future position of a number of industries in the centre countries is considered in relation to the periphery countries.

\section{INTRODUCTION}

Ever since the seventies the influence on world trade of the so-called developing countries has becn growing [1]. As we aim to illustrate the industrial relations of these countries with the high-income, highly industrialized countries, we prefer to call the latter the centre countries (the E.E.C. the U.S.A. and Japan) and the former, periphery countries, those outside these centres, mostly situated in Latin America, Asia and Africa. The growing industrialization and the increasing market of the periphery countries create on the one hand, more export and foreign production opportunities for the centre countries but on the other, a number of periphery countries is becoming more and more of a threat to the industries in the centre countries because of their growing exports in the world market. The most important periphery countries participating in world trade are the so-called Newly Industrializing Countries (the NICs) in Latin America (e.g. Brazil, Mexico, Venezuela and Argentina) and in South-East Asia (South Korea, Taiwan, Hong Kong, Singapore). Apart from this group, a second generation of NICs has come up in the last decade; countries such as India, Thailand, Indonesia, The Philippines, Sri Lanka, Malaysia, Morocco, Tunisia, Chile and maybe within a short period, China. A number of countries on the periphery of the original E.E.C. are becoming more influential as well. The new members Portugal and Spain, and Greece, Yugoslavia and Turkey should be mentioned here. The periphery countries that 
are hardly involved in the world market are the very-low-income countries, mostly situated in Africa.

The growing pressure from a great number of periphery countries on the centres, like the E.E.C., is manifested not only in the traditional sectors such as clothing, textiles and footwear but also increasingly in other industries, such as electrical products, fertilizers, automobiles and steel [2]. At the same time, internal competition within the E.E.C. is increasing, so that many enterprises are looking for chances outside, in the U.S.A. and Japan, but also in the periphery countries.

The central theme we wish to focus on for the above-mentioned reasons is the position of industries in the centre countries in their relation to the industrial capacities of the periphery countries. In this article the weaknesses and strengths of manufacturing systems in periphery countries related to manufacturing systems in centre countries are discussed. From that, conclusions are drawn concerning the selection and design of manufacturing systems in these countries and the international competitiveness of industries in the periphery countries. Furthermore, an international production-allocation model is presented, which determines the optimum location of manufacturing systems of internationally tradeable products and analyzes the sensitivity to competition from the periphery countries of the different industries in the centre countries.

Finally, the future position of a number of industries in the centre countries is considered in relation to the industrial capabilities of the periphery countries.

\section{INTERNATIONAL MANUFACTURING: A SYSTEM APPROACH}

If we wish to speak about international manufacturing, it is important to study the way industrial manufacturing takes place in different countries. The object of study is the manufacturing system in relation to its environment.
Since countries can differ considerably as to the availability and quality of production factors, and to market characteristics, the type and structure of manufacturing systems depends very much on the country. In terms of an input-output model [3] it can be said that a manufacturing system is influenced by the environment through its inputs, and that, on the other hand, the environment is influenced by the outputs of the manufacturing system. A manufacturing system will survive as long as the environment is able to deliver the inputs and accept the outputs. In general the inputs consist of material, energy, information, people and equipment, the outputs are (semi)products, waste, energy, information, obsolete equipment and people no longer engaged in the various manufacturing processes. According to the function of the inputs, one can say that people and equipment transform material into products with the help of energy and information.

The way the owners of a manufacturing system can operate in a certain environment is restricted by the constraints that the politicoeconomic institutions of the country impose on them. Examples of these constraints are: import restrictions and tariffs, labour laws, environmental pollution legislation, tax laws and capital transfer possibilities.

A manufacturing system is goal-oriented: in this study we assume that the primary goal of a manufacturing system is the generation of income for the owners within the constraints imposed by the politico-economic institutions. This means that a manufacturing system is maximally effective when it yields maximum profits. An important observation in this respect is that it depends very much on the existing politico-economic situation as to how far a high level of efficiency is necessary for high effectiveness [4]. In countries where industries are heavily protected, manufacturing systems can be effective without being efficient by international standards. 


\subsection{Structure of a manufacturing system}

In order to realize profits, an enterpreneur determines a production program: the type, quantity, quality and price of the products he intends to produce in a given period of time. This production program determines the required material inputs and transformation activities (the transformation system). The allocation of the transformation activities to people (the operators) and equipment (the technical system ) depends on their availability, quality and price; all of them aspects which can vary from one country to the next. In the allocation process the need for additional inputs (energy and information) are also of importance; they vary with the way of allocation. Finally, the allocation that will be chosen is the one that meets the quantitative and qualitative standards of the production program at minimum cost.

Apart from transformation activities, we distinguish regulatory activities (the control system ) necessary to control the functioning of the manufacturing system according to the production standards: the quality, quantity per time period (delivery time) and costs. This control system comprises of internal and external regulations (the acquisition of inputs, the distribution of the outputs and control over the imposed constraints ).

The structure of the manufacturing system is given in Fig. 1.

\subsection{The boundary of the environment}

It depends upon the type of the manufacturing system and the size of the country where the boundary of the environment lies. The envisaged marked can be very local (a village), national, or international, depending upon the product strategy of the firm and whether the necessary inputs can be obtained locally (within the nation) or internationally. How far the required inputs can be obtained locally and how far the envisaged market size can be at-

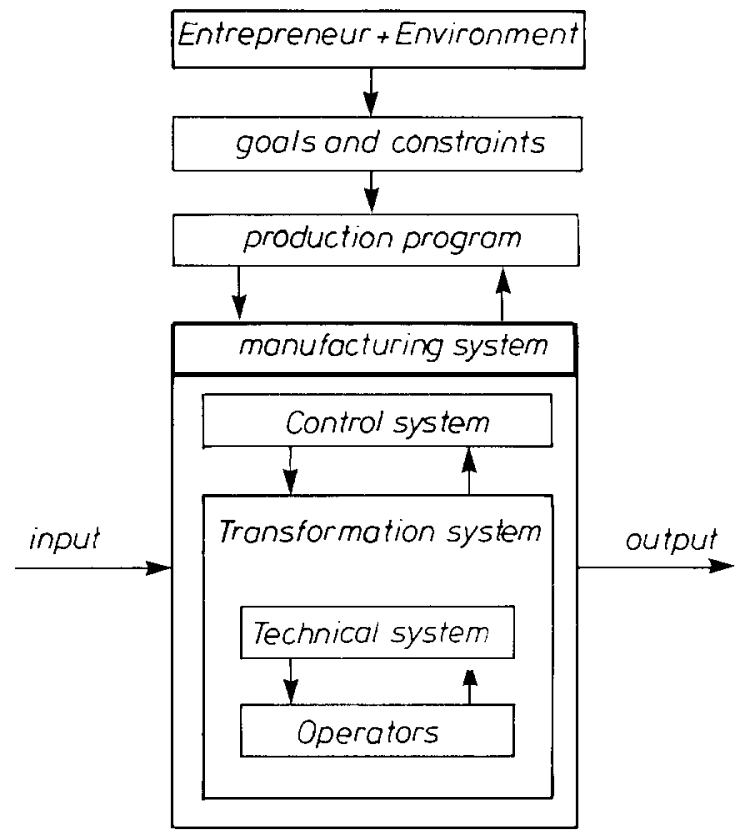

Fig. 1. General picture of a manufacturing system.

tained locally is connected to the size of the country considered:

- the geographical size (the availability of raw material)

- the population size

- the industrialization rate, the contribution to the GNP of the industrial sector (1-5 of the ISIC) and, within that the contribution of the manufacturing sector [5].

In Table 1 a survey is given of estimates of the size of a number of countries based upon these indicators.

From this table it is found that there are very few countries where larger manufacturing systems can operate entirely locally. Only in countries such as the U.S.A. and Russia nearly all the required inputs can be obtained locally, while the home market is sufficiently large in size. The other highly industrialized countries are dependent on external deliveries of energy (oil) and/or raw materials. More than $60 \%$ of the world market in mineral raw materials stems from low-industrialised, low-income countries and around $70 \%$ of the world market in agricultural raw materials is delivered by these last-named countries. The periphery 
TABLE 1

Market size, industrialization rate and availability of raw material and energy in a number of countries [6]

\begin{tabular}{|c|c|c|c|c|c|}
\hline Countries & Income & Market & Ind.rate & Raw.mat & Energy \\
\hline U.S.A. & 100 & 550 & ++ & ++ & + \\
\hline Canada & 95 & 34 & ++ & ++ & + \\
\hline France & 83 & 55 & ++ & - & -- \\
\hline Germany & 93 & 79 & ++ & -- & -- \\
\hline U.K. & 55 & 71 & ++ & -- & + \\
\hline Russia & 35 & 120 & ++ & ++ & ++ \\
\hline Japan & 62 & 100 & ++ & -- & -- \\
\hline Italy & 39 & 55 & ++ & -- & -- \\
\hline The Netherl. & 79 & 18 & + & -- & - \\
\hline Australia & 78 & 18 & + & ++ & -- \\
\hline Sweden & 110 & 16 & + & + & - \\
\hline Spain & 37 & 20 & + & + & -- \\
\hline Taiwan & 14 & 1.5 & + & -- & -- \\
\hline Mexico & 14 & 13 & + & + & + \\
\hline Brazil & 15 & 13 & + & ++ & + \\
\hline India & 2 & 5 & + & - & -- \\
\hline Greece & 33 & 5 & - & -- & -- \\
\hline Turkey & 13 & 3 & - & -- & -- \\
\hline Portugal & 22 & 5 & - & -- & -- \\
\hline Hong Kong & 27 & 3 & - & -- & -- \\
\hline Singapore & 28 & 1.5 & - & -- & -- \\
\hline Peru & 5 & 0.01 & -- & ++ & - \\
\hline Kuwait & 196 & 0.15 & -- & -- & ++ \\
\hline Zambia & 6 & 0.00 & -- & ++ & -- \\
\hline Tanzania & 2 & 0.00 & -- & -- & -- \\
\hline China & 4 & 10 & - & -- & ++ \\
\hline
\end{tabular}

Note: income is income per capita related to the U.S.A. $++=$ high $+=$ middle; $-=$ low $;--=$ very low. Industrialization rate as $\%$ of GNP.

Raw material includes minerals and agricultural products.

countries are mostly dependent on the centre countries for their semi-products and capital goods.

From the table it will be clear that industrial manufacturing above a certain scale mostly takes place across the borders of countries, and this applies to the inputs and the outputs concerned as well. This means that the boundary of the environment of these manufacturing systems is seldom the border of the country and mostly lies in an international field.

After having described a system approach to the study of international manufacturing, a short survey of literature in this field is given in order to see how far these theories can be useful to our approach.

\section{THE LITERATURE ON INTERNATIONAL PRODUCTION: A SHORT SURVEY}

The founder of the international trade theory is Ricardo (1817). He introduced the term comparative advantage, meaning that countries should specialize in those products that require the least hours of labour. Later, Heckscher (1919) and Ohlin (1933) developed the famous Heckscher-Ohlin theorem [7] stating that, because of different availability of labour and capital in different countries, international trade should be based on products using the most abundant production factor in the countries concerned. Tinbergen [8] translated this theorem in his theory on the international division of labour. His basic idea was to locate a certain industry where the necessary inputs of labour and capital correspond with the local availability of these inputs. Thus, labour-intensive industries should be placed in labour-abundant, low wage countries, and capital-intensive industries in capital-abundant countries (centre countries). Later, a number of comments were made by Tinbergen and others [9]. As labour and capital can not be considered as homogeneous production factors, the term human capital came up, explaining the well-known Leontiëf paradox (export of labour intensive products from the U.S.A. ).

Vernon [10] invented the product-life cycle theory for the explanation of international trade, resulting in the conclusion that periphery countries can only produce standardized mass consumer goods. Closely related with the product life cycle theory is the R \& D-intensity criterion: $R$ \& D-intensive products should be produced in centre countries with high availability of this human resource.

Stating that international trade is distorted by protection of local industries, 'I inbergen [9] pleads for free trade as protection only leads to economic disadvantages in the long term, for the producers as well as for the consumers in the different countries. Leibenstein [4] also 
suggests that protection creates a permissive environment for inefficient manufacturing systems.

\subsection{Some empirical facts}

Having mentioned the most important trade theories, we now consider the product streams between centre and periphery countries. The total volume of exports of industrial products from periphery countries only amounts to $6 \%$ of the world market [1]. The share of the periphery countries in the total imports of industrial products of the OECD countries is about $8 \%$ [11], whereby the NICs including the South European NICs (Spain, Portugal, Yugoslavia and Greece) supply more than $80 \%$. Some $40 \%$ of these imports to the OECD countries consists of traditional labour-intensive products such as footwear, textiles and clothing, but also more capital intensive products like metal products, automobiles and steel are entering the OECD. It seems that the skillintensity of the products from the NICs is increasing.

Amsden [12] found that $70 \%$ of the exports to the centre countries came from seven NICs (Hong Kong, Taiwan, Singapore, South Korea, Brazil, Yugoslavia and India) and that eleven NICs, the already mentioned NICs plus Mexico, Malaysia, Pakistan and Argentina represent $70 \%$ of the exports to the other periphery countries.

The most important South-to-South products are basic metals, machinery, automobiles, chemical products and textiles. Again it is stated that it is not the labour intensity which is the explanatory factor behind these exports. There is a fast growing export stream of capital-intensive and more skill-intensive products, despite the famous Heckscher-Ohlin theorem. The exports of the NICs to the centre grows at the rate of $16.5 \%$ /year while the growth rate of the exports from the centre to the periphery countries amounts only to $10 \%$ [1]. This increasing growth of exports from the
NICs leads to a reflection on the comparative advantage of the centres. According to Koekoek and Mennes [13] the centre countries have a comparative advantage in R \& D-intensive, high quality labour-intensive and capitalintensive industries.

\subsection{Micro approaches}

A limited number of economists have turned their attention to the analysis of international trends at the factory or micro level. Hirschman [14] proposed the hypothesis that machinepaced industries have a higher relative productivity in periphery countries than man-paced ones, and are therefore more favourable in these countries. Boon [15] found that the size of the market, and hence the batch size is an important criterion for industry selection in periphery countries. He also mentioned the product quality and the product range as influential factors and pinpoints that it is not only the labour-capital ratio that is important for industry selection in periphery countries but that the costs of energy, material and R \& D also have to be considered.

Strassman [16], Marley [17] and Tyler [18] carried out some research on the efficiency of industrial sectors in periphery countries. Their findings were that labour productivity in periphery countries is lower than in centre countries (in Mexico 5\%-60\% of the U.S.A. (Strassman) and in Indonesian textile industries $64 \%-70 \%$ of the U.S.A. (Tyler)), that, in general, multinationals have greater productivity and that protection has a negative influence on productivity. These findings however can only be considered as rough indicators for the efficiency at the factory level; more accurate figures and more insight into the causes of the lower productivity are needed before a good analysis of international manufacturing can be made. 


\subsection{Theory and practice}

This short literature survey makes it very clear that since Ricardo, and up till now, the theory of international trade has been based on only two production factors (inputs), namely capital and labour and that only a slight differentiation has been made in the labour factor. The other inputs in our manufacturing-system model (see 2.2.) are sometimes mentioned but are hardly ever used in the analysis.

According to the production factor capital the theories assumed that capital is scarce in periphery countries. Hirschman [14] already stated in 1958 that for industrial manufacturing, periphery countries have no shortage of capital but of "profitable funds". This is also evident from the investments in periphery countries of multinationals and large national enterprises as they have access to capital funds of international capital markets. If there is no difference of scarcity of capital between countries then it is only labour that is of importance for international manufacturing, so that we are back to Ricardo.

The empirical data on international trade show that the existing theories are inadequate in their explanation of the trade between centre and periphery countries. The explanation for this disparity between theory and practice can be found in our manufacturing-system model. There we see that manufacturing is based on five inputs instead of two; it is further evident that in international trade the transport factor has to be considered explicitly. Our starting point is that the owners of a manufacturing system strive to obtain maximum profits or minimum costs. This means that, in looking for the optimum manufacturing location they have to know the total costs per location, the quantities of all required inputs multiplied by their local prices. In the discussed theories the absolute numbers and costs are however lacking, which is the very reason why they are inadequate for discussions on internal manufacturing.
An entrepreneur is not interested in labour or capital intensity as a ratio, what counts in international manufacturing is the absolute number of labour hours per period of time, the labour content per year. Thus 12500 automobiles (each requiring around 20 labour hours) are as interesting for manufacturing in lowwage countries as 500000 pairs of trousers, each requiring $1 / 2$ hour of labour. Essential, however is the local labour efficiency in the low-wage country concerned, an almost totally ignored and hardly quantified factor in international trade. In the analysis of efficiency the labour factor has to be differentiated into operators, technological labour and control labour. As regards efficiency the last two labour types are of great importance, while in low-industrialised countries the scarcity of control and technological labour is high compared to that of operators.

In the following section we shall further elucidate the efficiency of manufacturing systems in periphery countries.

\section{THE EFFICIENCY OF MANUFACTURING SYSTEMS IN PERIPHERY COUNTRIES}

Efficiency is defined as the output/input ratio; the quantity of inputs used to achieve the desired outputs. Efficiency can be expressed in terms of material, energy, labour or capital used per output. In our analysis the emphasis is laid on labour efficiency, the output in physical units per labour period.

According to our manufacturing-system model the factors upon which the labour efficiency depends are:

- the control system

- the technical system

- the operators.

As far as the operators are concerned their performance depends on:

- their presence

- their work methods

- their pace. 
TABLE 2

Relative time spent on four main classes of activities of operators

\begin{tabular}{lcc}
\hline Class & Average $(\%)$ & Range $(\%)$ \\
\hline Technical work & 65 & $44-86$ \\
Control activities & 21 & $5-41$ \\
Personal care & 12 & $1-21$ \\
Unknown & 2 & $0-7$ \\
Total & 100 & \\
\hline
\end{tabular}

The work method and pace are determined by the skill of the operator, his physical state and his motivation. This line of thinking is taken for the analysis of the measured efficiency.

\subsection{Efficiency measurements}

An extensive research program was carried out in the metal-working industry in Peru [19]. In addition, a number of case studies has been carried out in a number of enterprises in several African and Asian countries (all low-industrialized countries ).

In Peru, work sampling was performed to determine the relative time required by the operators in 23 firms. The averages of the collected data (45000, weighted for the number of operators in each firm) are summarised in Table 2.

From the wide ranges it becomes evident that there are very great differences between firms. The value of the average percentages therefore is rather limited, especially when it is realised that the relative use of time is not a direct measure of efficiency. Therefore the total set of data was divided into two sub-sets based on the type of the manufacturing systems. In the analyses it was found that the type of layout discriminated very significantly between two different patterns of relative time consumption of the operators. At one end of the scale the layout is strictly product-oriented, as in line or flow manufacturing; at the other end the layout is process- oriented, as in the so-called functional layout.
TABLE 3

Relative time spent on four main classes of activities of operators

\begin{tabular}{|c|c|c|c|c|}
\hline \multirow{2}{*}{$\frac{\text { Type of layout }}{\text { Class of activity }}$} & \multicolumn{2}{|c|}{ Product-oricnted } & \multicolumn{2}{|c|}{ Process-oriented } \\
\hline & $\%$ & Range & $\%$ & Range \\
\hline Technical work & 74 & $65-89$ & 56 & $48-71$ \\
\hline Activities & 11 & $5-18$ & 30 & $17-45$ \\
\hline Personal care & 14 & $3-21$ & 11 & $1-20$ \\
\hline Unknown & 1 & $0-6$ & 3 & $0-6$ \\
\hline Total & 100 & & 100 & \\
\hline
\end{tabular}

By dividing the work-sampling data into two groups, product-oriented layout and processoriented layout, a rather interesting difference in relative time consumption comes to light.

From Table 3 it follows that the two types of manufacturing systems evidently show a marked difference in relative time consumption by operators. On comparing the results of Table 3 with Dutch industrial data, it was found that Peruvian product-oriented firms have about the same percentage of technical work as the product-oriented Dutch firms. Peruvian process-oriented firms, however have a lower percentage of technical work than comparable Dutch firms; $56 \%$ compared to $63 \%$. As the relative use of time is not a direct measure of efficiency, time and work-methods studies were carried out. It was found that in product-oriented firms, where operator tasks are rather simple and short-cyclic, the output per unit time was about $80 \%$ of the Dutch standard. Hence the time efficiently spent on technical work was $80 \% \times 74 \%=59 \%$, resulting in an average efficiency level compared to the Netherlands of $80 \%$.

Process-oriented firms in Peru presented another picture. Operator tasks in this type of firm vary from simple to rather complicated. It was found that output per hour in these firms varied from $30 \%$ to $50 \%$ of the Dutch standard, resulting in time efficiently spent on technical work of $17 \%(30 \% \times 56 \%)$ to $28 \%$ $(50 \% \times 56 \%)$. Compared to the Netherlands, 
this means an average efficiency level of $27 \%$ $(0.17 / 0.63)$ to $44 \%(0.28 / 0.63)$. The relative efficiency level thus calculated has been based on operators, (direct workers). Inclusion of the indirect workers (the control people), lcads to a much lower figure being found because of the higher ratio of indirects to directs in such countries. In Peru we found that this ratio was up to twice as high as in comparable Dutch firms. The case studies we carried out in other periphery countries, India, Tunisia, Egypt, Zambia, Surinam, Indonesia and Ghana, showed that labour efficiency in these countries is within the same range, albeit that Indonesia showed a somewhat higher level and the African countries a lower one.

Another feature, which is probably not so surprising, was that on the average, enterprises with western management in this type of country have a higher labour-efficiency level; according to estimates $70 \%-80 \%$ of the Dutch standard.

\subsection{The causes of lower labour efficiency in periphery countries}

\subsubsection{The control system}

Analysis of the causes of the lower efficiency shows that the majority of the time losses are due to lack of control of the manufacturing system (delays in material supply, lack of clear orders, lack of instruction in manufacturing methods, etc.). It was found that the internal part of the control system has serious drawbacks, poor quality control, planning, work instruction and provision of material. As to the external part of this system it was stated that long-term strategies hardly existed. The entrepreneurs are more active as traders than as long-term managers. The often unstable political environment undoubtedly is an important cause of this behaviour.

\subsubsection{The technical system}

The technical system gencrally is characterised by a collection of rather old machines with a low manufacturing velocity and a low accuracy level. As the quality standards of the products are far below that of centre countries, manufacturing is still possible. The average figure for manufacturing delays due to machine problems was around $20 \%$, caused mainly by lack of maintenance and adequate planning techniques.

\subsubsection{Performance of operators}

On comparing work-pace estimates with Dutch standards a significant difference could not be found. Moreover, the presence of operators was not lower than in Dutch firms despite their worse physical state. The main cause of lower performance lies in the work methods used, partly due to lack of skills and partly due to lack of instruction. Only in African enterprises, however, a very low level of skill on the part of the operators was encountered. The motivation of workers is generally high, owing to the poor social systems in the countries concerned.

\subsection{The selection of manufacturing systems in periphery countries}

The foregoing analysis of labour efficiency in the lower-industrialised periphery countries shows that it is essential to incorporate the local efficiency level in the decision-making process in manufacturing activities in these countries. The possible advantages of lower wages can easily be nullified by a low efficiency level. Furthermore it was found that the control intensity of the manufacturing system is decisive for the achievable local efficiency level. As the control intensity of product-oriented manufacturing systems is lower than that of process-oriented ones, manufacturing-cost advantages can be obtained first of all in pe- 
riphery countries in manufacturing products with a high annual labour content on a product-oriented basis; this means manufacturing on a larger scale with a limited product range. Manufacturing of products having a high annual labour content on a process-oriented basis (small lot sizes and big product range) can result in higher costs despite the low wage level. The possibilities for more control-intensive manufacturing are strongly dependent upon the local management capabilities. In the Asian NICs these capabilities are considerably higher than in the low-industrialized African countries. There, management for this type of manufacturing will have to be important at high cost.

\section{MANUFACTURING COSTS IN PERIPHERY COUNTRIES [20]}

After the determination of the efficiency level in periphery countries, the consequences of the lower efficiency and other manufacturing circumstances on manufacturing costs in these countries are now described. What we are interested in are manufacturing costs in periphery countries compared with manufacturing costs in centre countries. Manufacturing costs are defined here as the sum of labour costs and capital (equipment) costs. Thus,

$P=D_{1} \cdot L_{\mathrm{d}}+I_{1} \cdot L_{\mathrm{i}}+d \cdot C+b \cdot C / 2$

$P=$ manufacturing costs of a certain quantity of products per year; $D_{1}=$ total number of manhours directly involved in manufacturing (the operators ); $I_{1}=$ total number of man-hours indirectly involved in manufacturing (e.g. maintenance, management and controlling); $L_{\mathrm{d}}=$ hourly cost of direct labour; $L_{\mathrm{i}}=$ hourly cost of indirect labour; $C=$ total capital invested in machinery; $d=$ depreciation rate per year; and $b=$ interest rate.

Working capital costs are excluded from the formula, as generalizations of this cost type are difficult to make. Material costs and transport costs are excluded for the same reason. As to working capital, it can be assumed that if manufacturing costs, as defined above, are higher in a particular country, the working-capital costs are also higher. (In section 6 these costtypes will be included in an allocation model, using specific products.) Knowing manufacturing costs in centre countries, the question arises as to what happens to these manufacturing costs after the production system is transferred to a low-wage country where the same technology (the same equipment) is used. When considering manufacturing in low-wage, periphery countries the following factors are of importance:

Labour efficiency: Lower labour efficiency, as defined, causes a greater need for direct manhours as well as indirect man-hours and a greater amount of capital for a fixed quantity of products. As we have seen, labour efficiency in periphery countries ranges from $30 \%$ to $80 \%$ of the Dutch level.

Labour costs: In countries with very low wages, such as India and Indonesia, direct workers cost about $5 \%$ of what their western colleagues earn, and indirect workers cost about $20 \%$ of what similar workers earn in centre countries. For low-wage countries such as Peru and Ecuador, the costs ratios are $10 \%$ and $25 \%$ respectively, and for middle-wage countries like Tunisia and Morocco $10 \%$ and $30 \%$ respectively.

The rate of interest: A risk factor is introduced to express the higher risks for forcign investments in periphery countries.

Equipment costs: Transport, insurance, necessary adaptations and sometimes taxation, can increase the cost of equipment and machinery in periphery countries.

Organizational differences: Due to a less industrialised environment, to less qualified manpower and to cultural influences, a higher ratio of indirect to direct workers is found in periphery countries.

Using the above-mentioned factors, the expected manufacturing costs in periphery countries can be expressed in terms of western 
Relative manufocturing costs

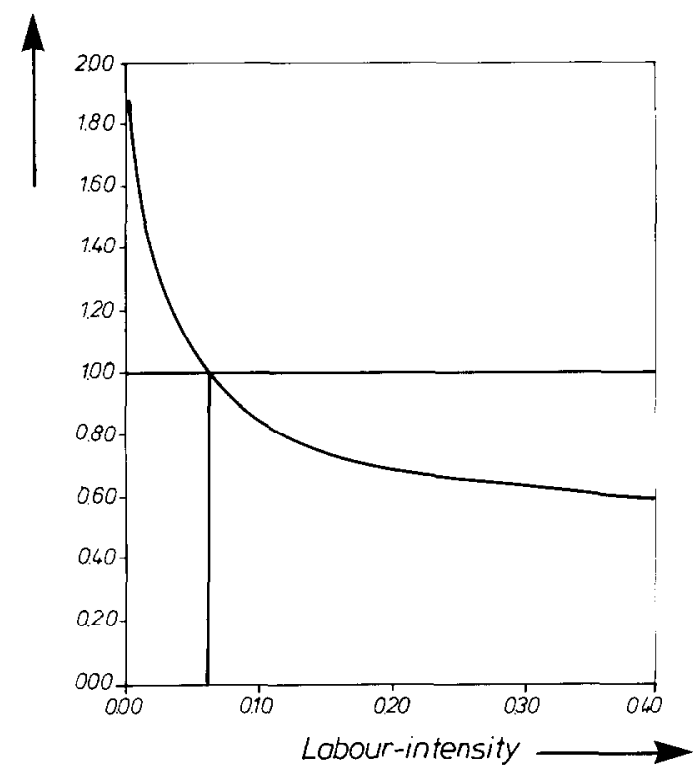

Fig. 2. An example of the relative manufacturing costs in a periphery country, [20].

manufacturing costs. A computer program was developed in order to simplify the calculation effort. Figure 2 shows the results of an example for which the following values are used compared to the Netherlands: labour costs $10 \%$, indirect labour costs $25 \%$, efficiency level $50 \%$, the ratio indirects/directs twice the Dutch ratio and interest rate $50 \%$ higher.

From Fig. 2 it can be seen that the critical value of the labour intensity for which no cost advantage can be obtained in this country is 0.06 hour per dollar. To the left of this point, manufacturing in a periphery country is more expensive while, to the right, manufacturing costs are lower. For the engineering industry ( 0.18 hour per dollar), for instance, the calculated manufacturing costs are $70 \%$ of those in centre countries. Figure 2 gives a first impression of the economic effects of locating certain industries in periphery countries. It is also possible to deduce from this figure the potential competition from these countries.

\subsection{Sensitivity analysis}

In order to perform a sensitivity analysis, the influence of the discerned factors on the expected manufacturing-cost advantages, i.e. on the shape and position of the curves, has to be known. The sensitivity of the relative manufacturing costs in periphery countries has been analysed with regard to

- the higher risk

- higher machine costs

- the relative wage level

- the relative higher number of indirects

- the lower relative labour efficiency (with respect to western standards).

From the sensitivity analysis it was found that production costs in periphery countries are rather sensitive to the risk factor and higher machine costs, especially so, of course, in the case of more capital-intensive manufacturing. It was found, moreover, that the impact of differences in wages within the group of low-wage countries has no great impact. The most important factors appeared to be the labour efficiency and the ratio of indirects/directs.

\subsubsection{Indirect labour and relative labour efficiency}

In the computer program the values of the variables used in the example given in Fig. 2 were varied by factors of $1 / 2,3 / 4,1 / 1,3 / 2$ and $2 / 1$. The resulting sensitivity analysis of the ratio of indirects/directs and the lower efficiency is shown in Figs. 3 and 4.

From Fig. 3 it can be deduced that when the ratio of indirects to directs is four times higher than in centre countries (curve 5 ), no cost advantages can be obtained.

Figure 4 shows that the effects are even stronger for variations in the efficiency of labour. Even when interest rate is $50 \%$ higher in periphery countries, local manufacturing is nearly always profitable when efficiency equals western standards (line 5). At this efficiency level the costs of manufacturing will be less 
Relative manufacturing costs

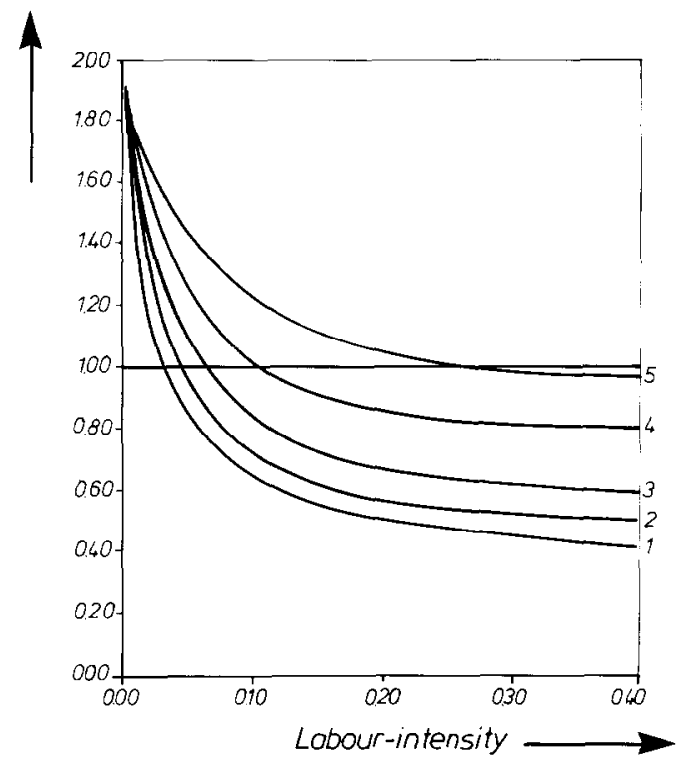

Fig. 3. Sensitivity of manufacturing costs to indirects [20].

than $40 \%$ of western costs for products with a labour intensity greater then 0.1 hour/dollar. However, when efficiency falls to $25 \%$ of that in western countries (curve 1), no industry

Relative manufacturing costs

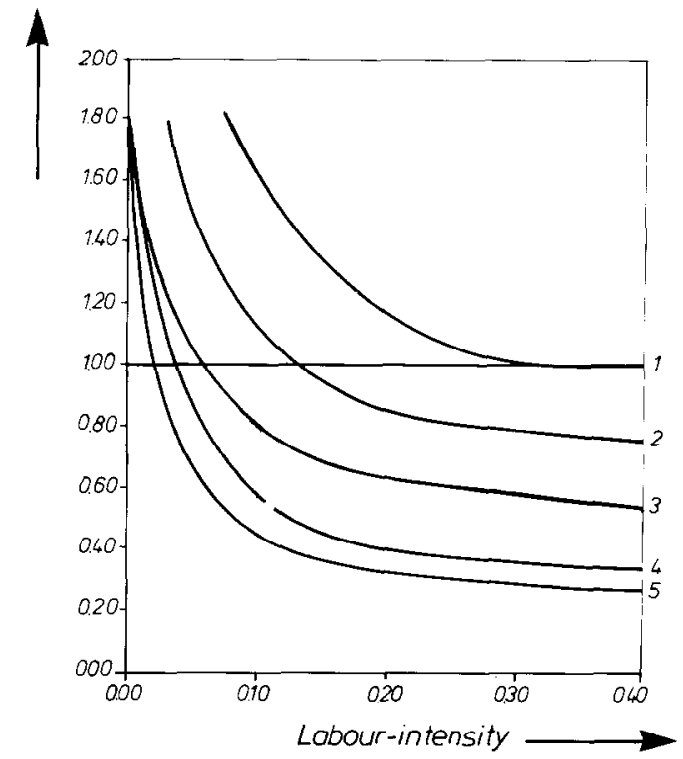

Fig. 4. Sensitivity of manufacturing costs to labour efficiency [20]. whatsoever will obtain advantages in periphery countries; even for the very labour-intensive clothing industry ( 0.35 hours/dollar) local manufacturing will cost $20 \%$ more, as indicated in Fig. 4.

The great influence of the labour efficiency on relative manufacturing costs is also important with regard to the batch size: the larger the batch size, the greater the relative labour efficiency as was noted in the discussion on product- and process-oriented manufacturing systems. This batch size effect can also be deduced from Fig. 4. Moving from curve 1 to curve 4, which can be interpreted as going from smaller to larger batches, the relative labour efficiency increases from $25 \%$ to $75 \%$.

\subsection{Conclusions}

In determining the location of manufacturing systems in low-wage periphery countries, the relative costs of labour are far less important than labour efficiency. For middle-wage countries like Tunisia and Morocco, however, the wage rate becomes more important. It has been shown that, for these countries, the minimum labour efficiency required is around $40 \%$ of that of western countries, in order to produce at lower cost. The great influence of the lower labour efficiency and the higher ratio of indirects/directs on manufacturing costs in periphery countries makes it clear that much effort should be put into management training in these countries. Furthermore, it is clear that the low-industrialized countries cannot be competitive without western management.

Finally, the sensitivity analysis presented here shows that the discussed economic literature on labour-intensive industries in periphery countries dangerously oversimplifies micro-economic reality. Even labour-intensive industries can be advantageous in periphery countries only if a number of stringent conditions are met. 


\section{INTERNATIONAL PRODUCTION ALLOCATION}

In the foregoing section possible manufacturing cost advantagcs in periphery countries was analyzed. Here international production allocation will be dealt with using an allocation model in which, in addition to manufacturing costs, material and transport costs are included. This model has been applied to a number of cases, from which indicative conclusions have been derived as to the sensitivity to international competition of industries in the centre countries and the consequences to reallocation and restructuring of these industries.

The basic elements of the model are:

- the location of raw materials

- the location of the market

- the manufacturing systems

- the different countries.

The problem which has been tackled is: minimization of production-system costs, the sum of material costs, manufacturing costs and transport costs, the production location being considered as a variable.

Countries differ according to the availability and hence the price of inputs and the distances to the raw material and market location. It was stated that countries also differ with regard to labour efficiency and other manufacturing characteristics (section 5). Taking the abovementioned factors into account, a simulation program (spread shect, lotus 1-2-3) was made, calculating the production-system costs in different countries [6]. The method used was that cost functions were constructed for certain quantities of products, based on data from Dutch and other European firms. These cost functions consist of all the quantities and prices of the required inputs in the different processes and the transport costs of materials and end-products. Knowing the cost functions of the product quantities produced in European countries, the simulation program calculates the expected system costs in other countries when transferring the manufacturing system to such countries. For each country that is considered for location, the actual values of inputs, transport prices and labour efficiency are introduced in the work-sheet program.

In the program a distinction was made between 3 types of labour: operators, technologists and controllers because of the great difference in availability and price of these labour types in the different countries. The required data from the countries involved were gathered by own research or the work of students preparing for their master's thesis. As the labour efficiency is the most crucial factor for the manufacturing costs in periphery countries, sensitivity was calculated with regard to efficiency for all the cases considered (see 6.1) The results of this exercise for poultry meat costs are presented, Fig. 5.

In the graph the costs for the Netherlands are assumed to be constant at all efficiency levels. The graph shows that the minimum required efficiency level in order to be competitive for France is $55 \%$ and that production in Brazil is cheaper for all efficiency levels higher than $40 \%$. For the other cases the same procedure was used and the results summarized here. The values used for the efficiency level in the allocation simulation are mentioned in Table 4.

The values of the efficiency used for the allocation simulations are based upon the characteristics of the manufacturing systems (product-oriented) and the average efficiency level was measured in the countrics concerned. The values for Zambia, Saudi Arabia and the Philippines are based on manufacturing with western management. For Spain we calculated the local costs for manufacturing of clothing with local management $(60 \%)$ and with foreign management $(70 \%)$.

\subsection{Simulation results}

The cases studied were continuously cast copper rods, fertilizers, tomato growing, canned vegetables, poultry meat and readymade clothing. In this section the simulation 


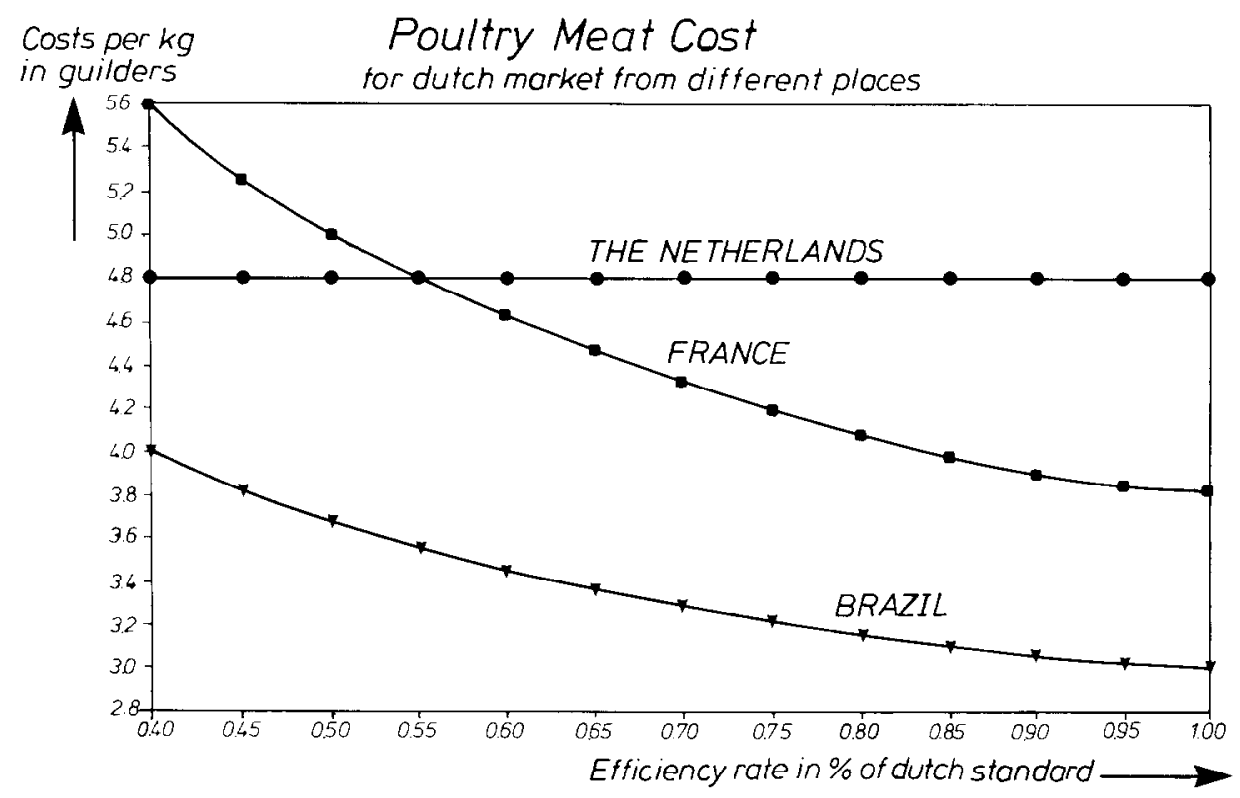

Fig. 5. The sensitivity of poultry meat production in France and Brazil with regard to efficiency.

TABLE 4

The minimally required efficiency level for cheaper production of the different cases and the efficiency values used in the simulation

\begin{tabular}{|c|c|c|c|c|c|}
\hline Case: & $\begin{array}{l}\text { Copper } \\
\text { semis }\end{array}$ & Fertilizers & Tomatoes & $\begin{array}{l}\text { Poultry } \\
\text { meat }\end{array}$ & Clothing \\
\hline $\begin{array}{l}\text { Minimally } \\
\text { required } \\
\text { efficiency }\end{array}$ & Zambia: none & $\begin{array}{ll}\text { India: } & 75 \% \\
\text { S.Arabia: } & 50 \%\end{array}$ & Spain: $55 \%$ & $\begin{array}{ll}\text { France: } & 55 \% \\
\text { Brazil: } & 35 \%\end{array}$ & $\begin{array}{l}\text { Spain: } 65 \% \\
\text { Phil.: } 20 \%\end{array}$ \\
\hline $\begin{array}{l}\text { Value used } \\
\text { in simulation }\end{array}$ & Zambia: $70 \%$ & $\begin{array}{ll}\text { India: } & 70 \% \\
\text { S.Arabia: } & 80 \%\end{array}$ & Spain: $60 \%$ & $\begin{array}{ll}\text { France: } & 70 \% \\
\text { Brazil: } & 60 \%\end{array}$ & $\begin{array}{r}\text { Spain: } 60 \% \\
70 \% \\
\text { Phil.: } 70 \%\end{array}$ \\
\hline
\end{tabular}

Note: Phil. stands for the Philippines.

results are presented first, after which the indicative conclusions are described as to the sensitivity to competition from periphery countries of industries similar to those of the cases presented.

\subsubsection{The production of continuously cast rods (CCR)}

CCR is used for the manufacturing of copper wires. For the production of CCR, refined copper is processed continuously into copper wires (8-20 $\mathrm{mm}$ thickness). In this case it is analysed whether it is economically feasible for
Zambia to export CCRs to the European market and whether the European producers are sensitive to competition from this copper-exporting country. The necessary data for this study were obtained from a German producer of CCRs and through a field study in Zambia. The results of the production allocation simulation are presented in Fig. 6.

For Zambia the following values were used: labour efficiency is $70 \%$ (western management ), labour costs are $15 \%$ of Dutch costs for operators and $25 \%$ for technologists. Costs for western managers are calculated at 300000 guilders a year. 


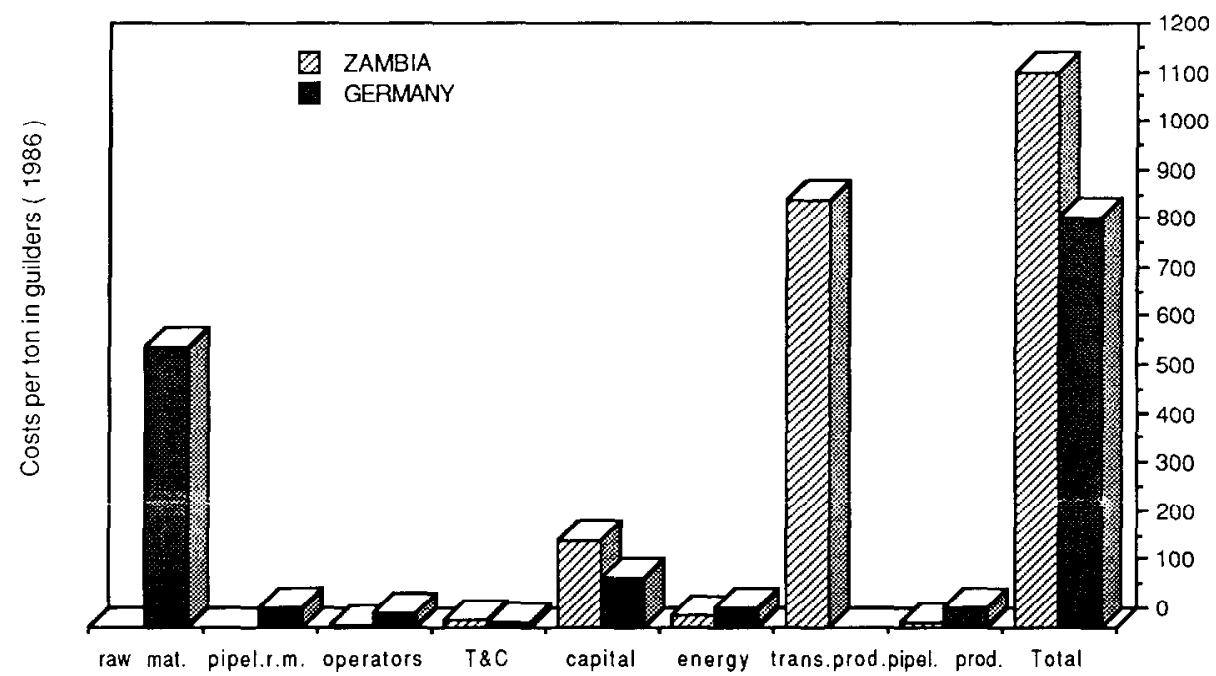

Fig. 6. Copper-semis production in Zambia and Germany for the European market: tr. raw mat. =transport costs of raw material; pipel.r.m. = pipeline costs of the transport of raw material; $\mathrm{T} \& \mathrm{C}=$ technologists and control-labour; trans-prod. $=$ transport costs of end products; pipel. prod. = pipeline costs of the transport of end products.

The graph shows that Zambia has a great cost disadvantage, about 300 guilders per ton compared to Europe. The advantages of lower labour costs (operators and technologists) and lower energy costs (hydro power) are outweighed by the greater capital costs (caused by the lower efficiency) and the very high transport costs. The high transport costs are caused by the container transport of the products, necessary for the protection of the copper wires.

\subsubsection{The production of fertilizers}

The production of fertilizers is an example from the chemical industry. In this case the aim is to determine the extent to which the production of fertilizers, which is marked by high capital investments, a high energy input (natural gas ) and a high technology intensity, is bound to locations in highly industrialised countries. Up to the present a considerable part of the required fertilizers is imported by the less industrialised countries; $40 \%$ of local consumption. The E.E.C. also plays an important role in exports to these countries. The question which is posed here is whether less-industrialised countries, which have access to natural gas, can pro- duce fertilizers at lower costs than are incurred in imports. In this case fertilizer production is studied in India, Saudi Arabia and the Netherlands.

Also investigated is the extent to which oilexporting countries such as Saudi Arabia can eventually influence the world market for fertilizers, taking into consideration the high degree of availability of natural gas in those countries. The case study under consideration is based on a production of 300000 tons fertilizers (NPK 17-17-17) per year. The technology applied is assumed to be the same in all locations, which is rcalistic in vicw of the fact that the factories have been built under licence from western enterprises.

In the calculations for Fig. 7 we assume for India an efficiency of $70 \%$ compared to the Netherlands with local management and in that of Saudi Arabia the starting point was $80 \%$ relative efficiency, because production there is carried out under western management and western tecnologists (expatriates).

From the graph it is clear that Saudi Arabia enjoys a considerable cost advantage (about Dfl. 50 million per year) as the result of the great raw material advantages (the price of 


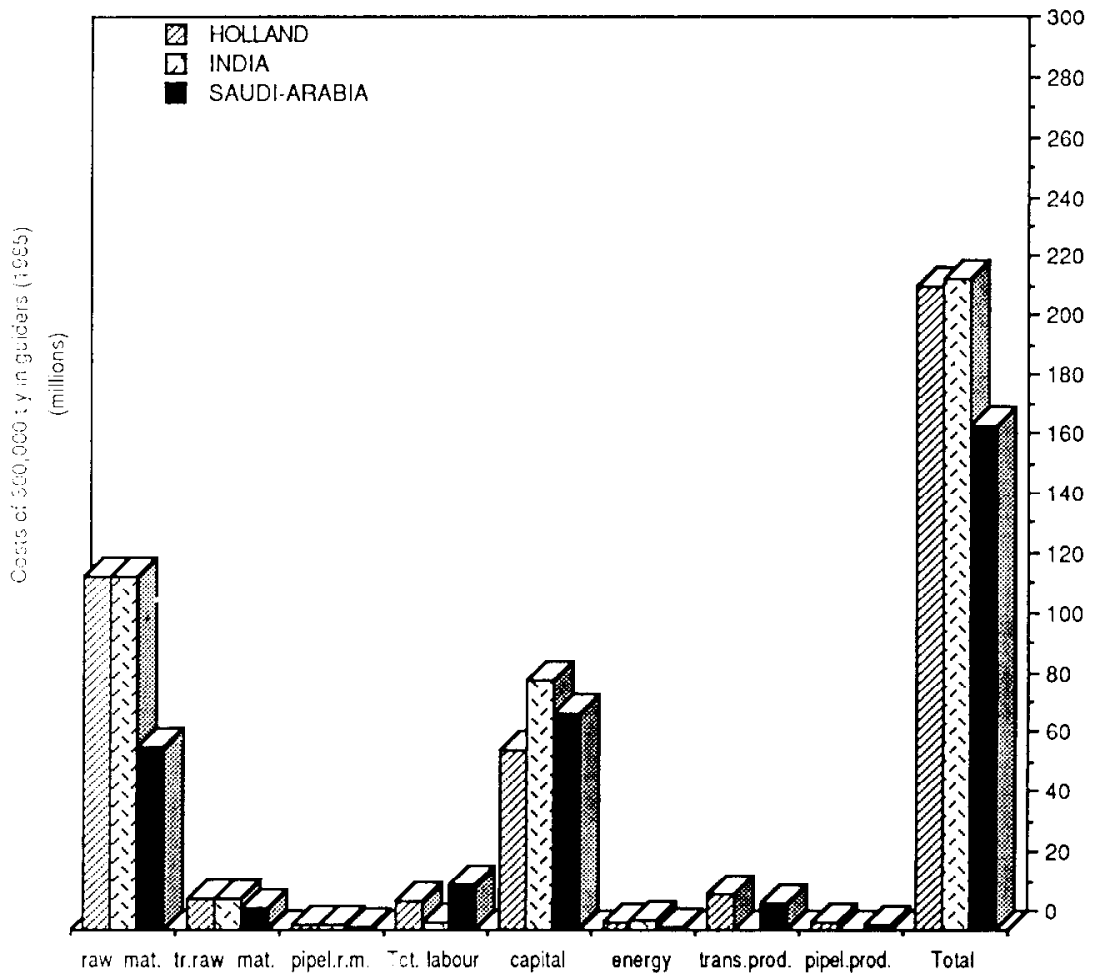

Fig. 7. Fertilizer production in Holland, India and Saudi-Arabia for the Indian market. (Tot. labour=total labour costs).

natural gas there is $20 \%$ of the price in the Netherlands) and in spite of higher capital and labour costs arising from the lower efficiency, and in spite of high technology and management costs.

India, where there is a shortage of fuel, including natural gas, appears at this moment to be scarcely in a position to compete in production comparcd to Europcan producers because of the still too low efficiency factor. This causes an increase in capital costs, which is insufficiently compensated by the lower labour costs. Compared to potential producers of fertilizers from the OPEC countries, such as Saudi Arabia, countries like India can be described as having no chance. For both Europe and India it is a fact that the extra transport costs from Saudi Arabia ( \pm Dfl. 35/ton) are in no proportion to the production-cost advantage in Saudi Arabia of \pm Dfl. 170 per ton.

\subsubsection{The production of tomatoes and the canning industry}

Tomato production has been chosen as an example from the agricultural and horticultural sector. This is done to determine whether countries with a high degree of solar heat and lower wages can enjoy an advantage in production. In Fig. 8 a comparison was made between Spain and the Netherlands on the basis of production of 370 tons of tomatoes per year for the Dutch market.

It was found that the Spanish cultivator's production of 370 tons gives him an advantage over his Dutch competitor of Dfl. 100000 per year even though the former's efficiency factor is only $60 \%$. This is due, in the first place, to very low energy costs, notwithstanding the higher technology- and control costs that follow from the lower efficiency already men- 


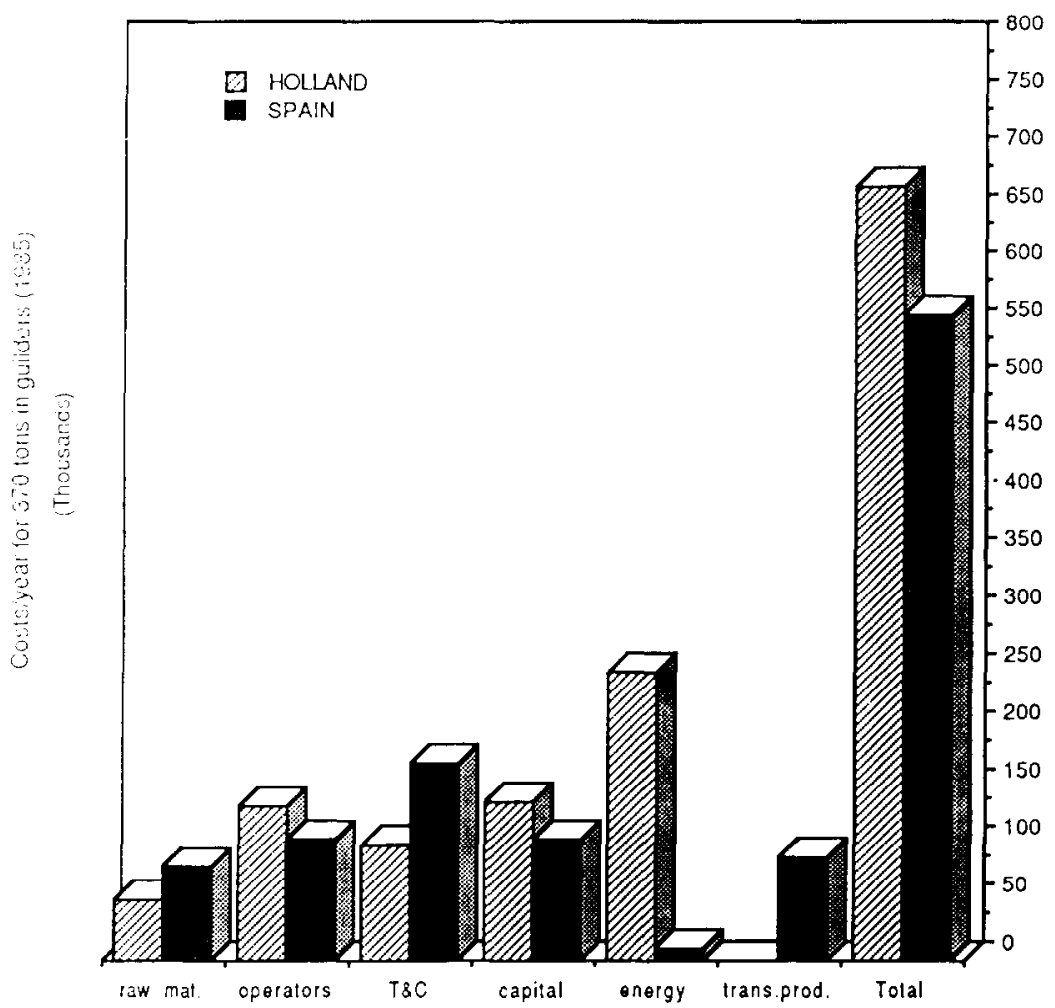

Fig. 8. Tomato production in Holland and Spain for the Dutch market.

tioned, to say nothing of the high cost of transport to the Netherlands. Capital costs in Spain are also lower, as investment costs are much lower there too (plastic greenhouse).

An investigation, linking up with the study on the optimum international location for tomato growing, has been carried out into the position of the Netherlands in the vegetableprocessing industry. The growing and canning of vegetables in the Netherlands, compared with supplying that market from Tunisia, was the situation to be analysed.

The results of investigations carried out both in a Dutch and a Tunisian enterprise showed that in practically every case the Tunisian products are the cheaper ones. The main determining factor is the much lower price of the land in Tunisia (10\% of the Dutch price), followed by the lower labour costs, particularly for strawberries and asparagus $(20 \%$ of the costs in the Netherlands).

\subsubsection{Production of poultry meat}

The production of poultry meat is an example from the food processing industry. Seen as a whole, the production of poultry meat is characterised by a high consumption of raw materials from agriculture (maize, tapioca and soya) which are largely obtained from tropical areas. In addition, the labour factor plays an important part in the final processing. The production of poultry meat in the Netherlands is based on imported raw materials. In view of the fact that only about $30 \%$ of these raw materials are finally converted into poultry meat, it is possible to achicve considerable savings in transport costs in places where the raw materials are themselves produced. This, added to the role of the labour factor in production and the continually increasing accumulation of dung, determines the extent to which this 


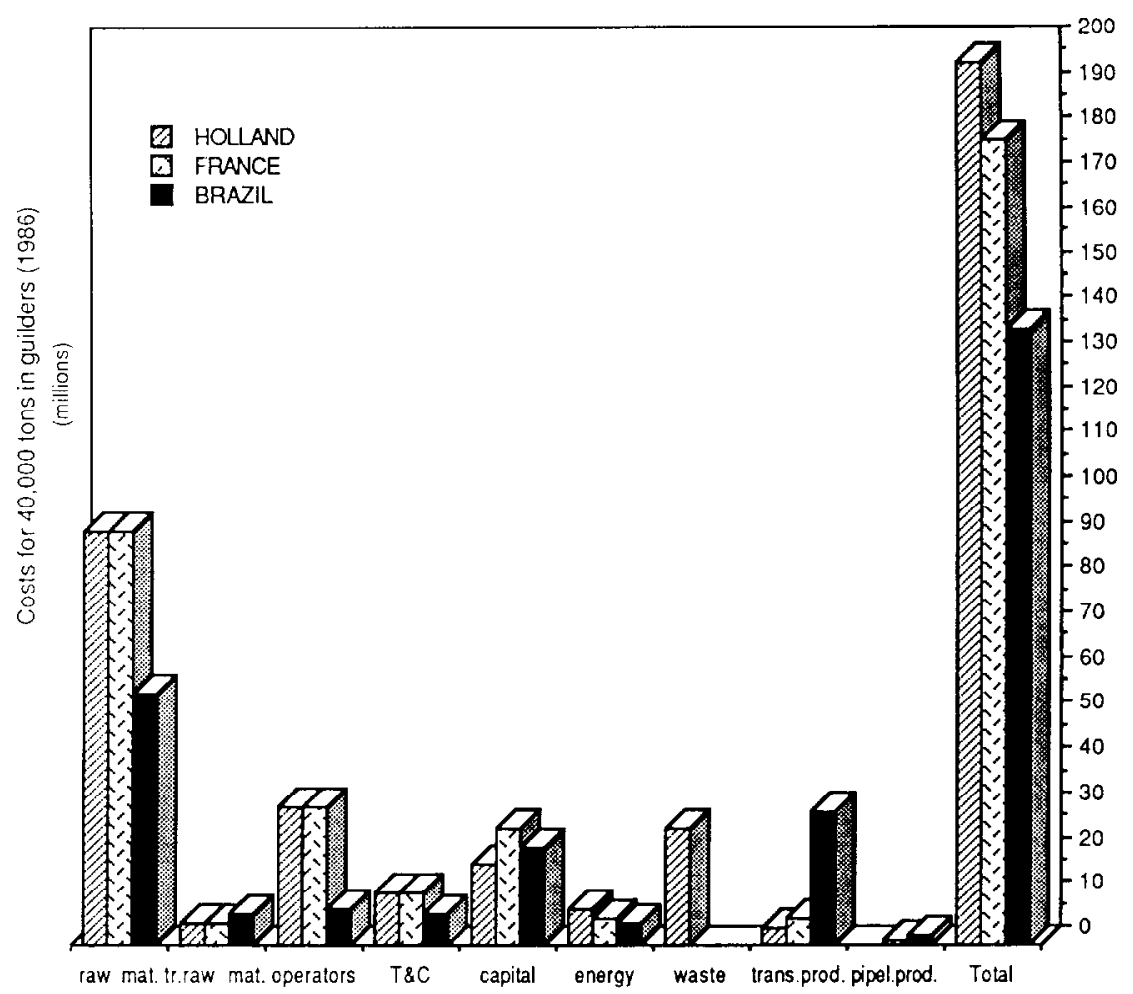

Fig. 9. Poultry meat production in Holland, France and Brazil for the Dutch market.

branch of the industry can be threatened by international competition. In this study we have considered two alternative locations, France and Brazil: The first because of the availability of maize and the short distances involved in transport to the Netherlands, the second because of the availability not only of maize but also of soya, tapioca and the low local wages. In addition, both countries are unaffected by the problem of the excess dung accumulation which is assuming ever greater proportions in the Netherlands.

In the simulation we took as an example the production of 40000 tons of poultry meat (from egg-laying battery, via hatchery, fattening station and slaughterhouse, up to and including distribution) on the basis of data obtained from a Dutch enterprise.

Figure 9 shows that France has cost advantages compared to the Netherlands amounting to \pm Dfl. 15 million per year, whereas Brazil with its lower efficiency $(60 \%)$ has consider- ably lower costs ( \pm Dfl. 60 million per year less than the Netherlands).

The costs advantages on the part of France are to be found mainly in the free removal of dung. These advantages outweigh the increased capital costs (at lower efficiency) and the higher transport costs of the end product. The factor which determine the high cost advantage of Brazil are given in order of importance: cheap mixed fodder, free removal of dung and low wages $(20-30 \%$ of those of the Netherlands). The grain levies customary in Europe (rising to $40 \%$ of the value of the imported grain ) do not apply in Brazil.

\subsubsection{The ready-made clothing industry}

The reasons why the ready-made clothing industry is being discussed with reference tosensitivity to international competition is the fact that this branch of industry is characterized, on the one hand, by a high labour content 
per product and, on the other, by production at short delivery times caused by the sensitivity of the articles with regard to fashion. Lowwage countries should perhaps enjoy an advantage as regards manufacturing costs, and in the same way suffer a disadvantage arising from long delivery terms. This is the main theme under investigation in the ready-made clothing sector. The Dutch enterprise produces 360000 pieces per year on the basis of short-term delivery.

The situations which are taken into consideration are the possibilities of production in Spain and the Philippines for the Dutch market. Spain is considered from the point of view of its relative proximity to the Dutch market, its lower wages $( \pm 50 \%$ of those in the Netherlands) and the absence of import tax arising from the country's membership of the E.E.C. The Philippines are viewed against a background of very low wages ( $\pm 5 \%$ of those in the Netherlands).
In the case of Spain we analyzed the situation with local management and an efficiency of $60 \%$ (SP (local)) and that of imported management and an efficiency of $70 \%$ (SP (forcign man.)). The starting point for the Philippines is $70 \%$ efficiency with Western management, in which two transport media are concerned - air freight ( $\mathrm{PH}$ (air)) and sea freight (PH (ship)).

From Fig. 10 it is found that Spain has a maximum cost advantage of Dfl. 1.75 million compared to the Netherlands and furthermore, that production in Spain with imported management must be given preference. In the case of local management the production costs turn out to be not much lower than in the Netherlands situation.

The extension of the delivery time in the case of Spanish production amounts to about one working week, arising from the transport time of the end product. With regard to production in the Philippines for the Dutch market, it is

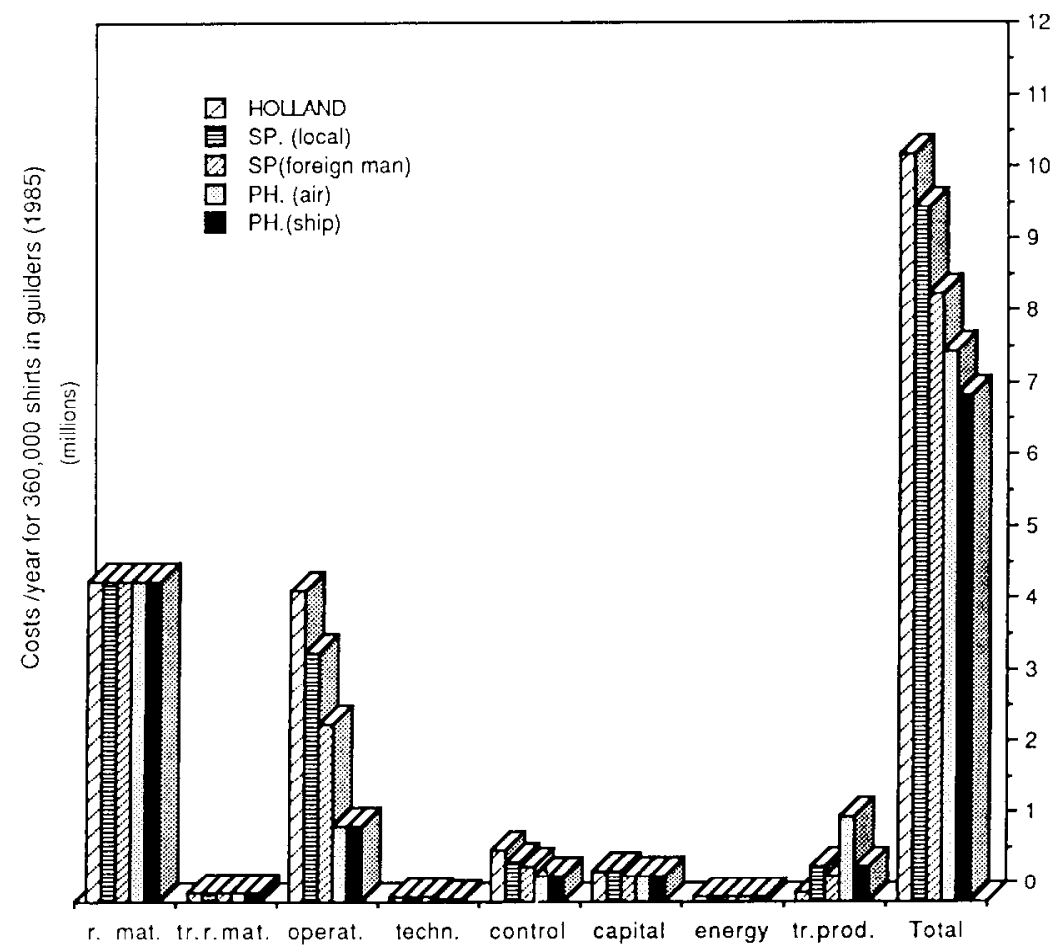

Fig. 10. Production of clothing in Holland, Spain and the Philippines for the Dutch market. 
found that sea freight brings an advantage of Dfl. 3.4 million per year whereas the delivery time is extended by five weeks. With air freight the advantage is Dfl. 2.8 million. The delivery time is however increased by only one week. Comparison of the Netherlands with the alternative locations Spain and the Philippines, shows that the advantages in Spain are slight compared with those in the Philippines. In this case it is labour which is the decisive factor determining allocation.

\subsection{The sensitivity of the central countries to competition from the periphery}

When the studies that have been carried out are compared with one another, very clear-cut differences are found regarding the factors that are important in the international allocation of production. Table 5 gives a summary of this.

The factors in this table are numbered on the basis of their influence on production allocation (ranking order 1, 2 and 3 ). The technology and control intensity are determined respectively by the number of man-years required in the Netherlands for technology and control work, divided by the total number of man-years required.

What is striking is the correspondence in control intensity of the manufacturing systems investigated. This is low throughout as the result of the product-oriented manufacturing structure encountered in all cases. According to the Table 5 and the cases concerned, some indications are given for the possible competition-sensitivity of a number of branches of industry.

\subsubsection{Nonferrous semi-manufactured products}

From the results of the case study of continuously cast wire, it can be stated that the manufacturing costs of copper semi-manufactured products are not lower in the periphery countries. In Table 5 we see that the transport costs are the most important allocation factor. The high price of the raw materials and the high gravity of refined copper inclines one to a pro-

TABLE 5

The most important allocation factors of the manufacturing systems investigated and their technology-and control intensity

\begin{tabular}{|c|c|c|c|c|c|c|}
\hline $\begin{array}{l}\text { Product group } \\
\text { Factor }\end{array}$ & $\begin{array}{l}\text { Copper } \\
\text { semi-manufac prods. }\end{array}$ & Fertilizers & Tomatoes & Vegetable canning & Poultry meat & $\begin{array}{l}\text { Ready-made } \\
\text { cloth. }\end{array}$ \\
\hline $\begin{array}{l}\text { Transport } \\
\text { Land }\end{array}$ & 1 & & & 1 & $1^{\mathrm{b}}$ & $3^{a}$ \\
\hline Raw materials & & & & & 1 & $1^{\mathrm{c}}$ \\
\hline Energy (raw mat) & & 1 & & & & \\
\hline Energy (heat) & & & 1 & & & \\
\hline Energy (electr) & 3 & & & & & \\
\hline Labour & & 3 & 2 & 2 & 2 & 2 \\
\hline Capital & 2 & 2 & 3 & 3 & & 3 \\
\hline Waste & & & & & 3 & \\
\hline $\begin{array}{l}\text { Technology } \\
\text { intensity } \\
\text { Control }\end{array}$ & $8 \%$ & $31 \%$ & $3 \%$ & $-{ }^{a}$ & $6 \%$ & $1 \%$ \\
\hline intensity & $4 \%$ & $5 \%$ & $5 \%$ & - & $5 \%$ & $4 \%$ \\
\hline
\end{tabular}

No data available.

"In this case the feeding costs are the most important, but these are for the greatest part determined by the land prices.

"The (raw) material costs are to a considerable extent labour costs.

dDelivery time. 
duction location in the vicinity of the raw materials. As no raw materials are lost in manufacturing of copper semi-manufactured products and transport of the end product is determined by wcight and has to be carried out in containers, the transport costs of the end product will be higher than those of the raw materials. This means that such industries will have to be or remain located near the market, in view of the vicinity of the customers in this situation. The large selling markets are to be found in the centre countries.

For the E.E.C., Japan and the U.S.A. this means that there is scarcely any competition to be expected from countries exporting refined copper, whereas a possible exception can be made for exports from Chile and Peru to the U.S.A.

For the copper-producing countries themselves, this means that only the bigger countries can produce copper semi-products for their home market on an economic basis, in which case they will also have to orient themselves to the regional markets in their vicinity. In that case, of course, there is a transport costs advantage compared to competitors from the West and Japan. Probably the same conclusion can be drawn for other ferrous and nonferrous products as semi-products on the basis of steel, aluminium, zinc and lead, as they are based on one and the same production technology.

\subsubsection{Chemical industry}

In the production of fertilizers, an example of the chemical industry, the total costs are in the first place determined by the raw materials (energy) as can be seen from Table 5 .

The specific aspect of fertilizers based on natural gas, is the linkage to the place where the gas is obtained in countries where there are no wide-ranging pipeline networks. Other chemical industries often use mineral oil derivatives as raw material (naphtha) and are for that reason not bound to the location of the raw material, since mineral oil derivates are avail- able everywhere at world market prices.

Critical in the location of chemical industries is in fact the utilization rate of the capital investment, the second factor determining allocation. The high technology intensity $(31 \%)$ indicates what the main reason is for eventual under-utilization (mainly maintenance) and likewise indicates that chemical technologies can only be transplanted to those countries where an adequate level of industrial knowledge exists. The high capital needs and the large "economies of scale" in chemical industries indicate the necessity for local markets of adequate size. This means that local production can take place only in the larger periphery countries (e.g. India, Indonesia, Thailand and the larger Latin-America countries) provided the efficiency is sufficiently high. Western support is apparently still necessary in many cases.

The OPEC countries deserve separate mention. In addition to large quantities of natural gas, these countries also have at their disposal a great deal of well-head gas (burn-off gas) from which a number of important raw materials can be made for the chemical industry. These raw matcrials are produced up to the present day in Western Europe on the basis of naphtha.

Ever since the energy crisis, the OPEC countries in the Middle Fast have been investing ever more oil dollars in chemical industries, the technology-and-control labour (the third factor) being imported on the selfsame dollar basis. This means that a great competition can be expected in the world market from OPEC countries both in the fertilizer industry as well as in the heavy chemical industry, both based on cheap raw materials (the most important allocation factor).

The foregoing means that export of fertilizers and other chemical products from the E.E.C. will probably be reduced in future. The home market of the European producers (E.E.C.) can only be protected in the short and medium-long term by import levies. 


\subsubsection{Horticulture in greenhouses}

It can be shown from the case of tomatoes that cultivation of vegetables in greenhouses is sensitive to competition from countries with a great deal of solar heat (no natural gas required) and cheap labour forces. An extra advantage enjoyed by these countries is their lower capital requirement as, after all, the greenhouse is a heat insulator in the Netherlands.

The relatively low technology intensity indicates a high degree of transferability of such manufacturing systems, which means that in these countries only slight differences in efficiency are to be expected. In view of the transport costs and the restricted keeping quality of fresh vegetables, it will be mainly the countries round the Mediterranean that will provide for a significant growth in competitiveness in these industries.

\subsubsection{Vegetable canning}

The optimum location of vegetable canning is, in view of production costs, to be found where the prices of fertile land are low, and where labour is cheap. Solar heat is supplied free at every location, and countries with a great deal of solar heat have the advantage that several harvests per year are possible. It can be assumed that the technology is transferable to the same extent as horticulture in greenhouses. All this could mean that the vegetable-canning industry in countries like the Netherlands and France could eventually be open to greater competition from countries such as Tunisia, but also from even more remote ones, such as China. This is particularly the case where products involving relatively more harvesting labour are concerned, for instance mushrooms, strawberries and asparagus, especially when large quantities are produced, resulting in lower transport costs per unit. At the present time the import levies imposed by the
E.E.C. prevent competition from those countries.

\subsubsection{The bio industry}

Analysis of poultry-meat production shows that raw materials and land are the most important allocation factors, followed in second place by the labour factor, with environmentpolluting waste coming third (dung). It must be observed that, where the concentration of dung production is high, as is the case in the Netherlands, dung is no doubt a pollutant of the environment. In countries like France and Belgium the problem does not arise.

The production of pork, likewise a Dutch export product of some importance, faces the same cost structure and dung situation, so that this branch of industry is in the same problem area. From the international viewpoint it seems justified to assume that, in the long run, the integral production of pork and poultry meat will shift to countries with more agricultural land and lower wage structures. There, fodder can be produced more cheaply, thanks to lower land prices. Cheaper labour is available and there is no dung problem. Within Europe, France is becoming attractive in this sense. Outside Europe, countries such as Brazil and Argentina are liable to form a threat to meat production in the E.E.C. The low technologyand-control intensity indicates that, at these locations, it is possible to achieve a relatively high efficiency level. The disadvantage of the high transport costs of deep-frozen meat to the E.E.C. market is largely compensated by the low fodder and labour costs, and by the absence of high transport costs of fodder. It should be noted that, since the final material efficiency in this form of industrial production comes to only $\pm 33 \%$, the transport costs of 1 ton of frozen poultry meat should be compared with 3 tons of fodder. 


\subsubsection{The ready-made clothing industry}

In this industry the labour costs are by far the most important factor. In the case investigated they amount to $80 \%$ of the total costs. It is thus not surprising that the production of ready-made clothing in countries with low wages and a reasonable level of efficiency which, in view of the very low technology intensity and low control intensity, is quickly achieved, leads to much lower manufacturing costs.

Against this there is an extension of the delivery times due to longer transport times of the end products. The degree to which one can speak of an extension of the delivery times depends on the means of transport, that is aircraft or ship. The calculations carried out in this case show that the extension of delivery times in the case of air transport is marginal $( \pm 10 \%)$ and that the higher transport costs are largely compensated by the much lower manufacturing costs. Here it should be noted that in reality the production costs in South-EastAsian countries will be much lower still than the calculations indicate, as a result of lower local material costs, again as the result of the share of labour involved.

Extension of the delivery times due to delays of incoming orders is scarcely to be expected in view of the rapid development of the telecommunication technology in the South-EastAsian region. The here-mentioned factors indicate that production of ready-made articles with short delivery terms can take place in South-East-Asian low-wage countries too. The physical proximity of the selling market and the production system will, in the medium-long term, come to play a steadily less vital role in those products which require a large number of working hours on an annual basis. This can be a limited quantity of products, requiring many working hours per unit, for instance ships, or a great quantity with a low number of working hours per unit, for example trousers.

The extent to which the lines sketched out for ready-made articles can be extended to other assembly-type discrete manufacturing systems, such as the production of televisions and motor cars, cannot be indicated here. It can likewise be assumed that even in such manufacturing systems, the possible annual export of cheap labour hours will continue to play an important part in the long-term allocation, in spite of the high degree of automation, and thanks to the large numbers involved. An example of this is South Korea's rapidly growing export of motor cars, based on low wages, high efficiency and well-trained technologists and managers.

\subsection{Conclusions}

The results of the allocation analysis can be used by Western entrepreneurs for reallocation of the existing manufacturing systems, or for modifying the manufacturing systems to ensure lower vulnerability. The cost functions which have been set up and the international analysis which has been carried out, specify the inputs to which the changes must refer by explicitly stating how the total costs are affected by the various inputs and their prices.

In the case of investment decisions in periphery countries the model can be used to make an estimate of the local production-system costs that are to be expected, so as to obtain insight into the economic viability of the planned manufacturing system. This is of importance both to local enterprises and multinationals.

The case studies that have been carried out show that all the factors affecting production (in the model these are all the inputs and transports ) must be taken into account so as to achieve a correct international production allocation. The economic theory of international trade which is based mainly on labourcapital relationships is therefore only reservedly applicable to allocation strategies and should be supplemented with product studies based on international cost functions. When a 
limited number of enterprises in a branch of industry is investigated by the methods described, it is possible to find indications touching on the sensitivity to international competition of the branch of industry concerned.

Finally we wish to remark that the production allocation exercises prove that the threat from the periphery countries to the E.E.C. is restricted not only to the, traditionally called, labour-intensive products. Also products requiring high investments, high-skilled labour or large energy inputs can be very sensitive to competition from the periphery countries. The most threatening group of periphery countries for the E.E.C., as far as manufactured products are concerned, are the NICs and the secondgeneration NICs in Asia. There the manufacturing capabilities increase rapidly resulting in a high level of efficiency. This coupled with low wages makes them a serious competitor in all kinds of tradeable manufactured products.

\section{REFERENCES}

1 Balassa, B., 1981. Trade in manufactured goods: patterns of change. World Develop., 9(3).

2 Helleiner, G.K., 1983. Manufactured export from less developed countries. Econ. J., 83.

3 Parnaby, J., 1979. Concept of a manufacturing system. Int. J. Prod. Res., 17(2).

4 Leibenstein, H., 1966. Allocative efficiency vs. X-inefficiency. Amer. Econ. Rcv, 46 (1).

5 Sutcliffe, R.B., 1971. Industry and Underdevelopment. Addison-Wesley, London.
6 Ven, A.D.M. van de, 1986. Internationale Industriële Productie. Ph.D. Thesis. Eindhoven, ISBN 90-900 1201$X$, Eindhoven University of Technology.

7 Södersten, B., 1970. International Economics. Harper and Row, London.

8 Tinbergen, J., 1958. The Design of Development. Baltimore.

9 Tinbergen, J., 1980. Which sectors stimulated by a recovery policy. Lloyds \& Bank Rev., 137.

10 Vernon, R., 1966. International investment and international trade and the product cycle. Q. J. Econ.

11 OECD, 1982. Development co-operation, Review.

12 Amsden, A.H., 1980. The industry characteristics of intra-third world trade in manufactures. Econ. Develop. Cult. Change, 29(1).

13 Koekoek, K.A. and Mennes, L.B.M., 1984. Revealed comparative advantage in manufacturing industry. The case of the Netherlands. De Economist. 132(1).

14 Hirschman, A.O., 1958. The Strategy of Economic Development. New Haven.

15 Boon, G.K., 1980. Technology and Employment in Footwear Manufacturing. Sijthoff and Noordhof, Alphen a/d Rijn.

16 Strassman, P., 1968. Technological Change and Economic Development. Cornell University Press.

17 Marley, S.A., 1977. Limited search and the technology choices of multinational firms in Brazil. Q. J. Econ., 2.

18 Tyler, W.G., 1979. Technical efficiency in production in a developing country: an empirical examination of the Brazilian plastics and steel industries. Oxford Econ. Pap., $31(3)$.

19 Beer, C. de, and Ven, A.D.M. van de, 1980. The efficiency of production systems in developing countries; a case study in Peruvian metalworking industry. Manage. Int. Rev., 20.

20 Ven, A.D.M. van de, and Luijk, J.F.A.M. van, 1986. Production in less developed countries: a sensitivity analysis. Eng. Costs Prod. Econ., 10: 235-243.

(Received January 19, 1988; accepted February 1, 1988) 